\title{
A comparative analysis of the effects of mentoring among participating countries in 2013 and 2018 Teaching and Learning International Survey (TALIS)
}

\author{
Alegado, Paul John Edrada \\ Faculty of Humanities and Social Sciences, Beijing University of Technology, China \\ Institute of International and Comparative Education, Beijing Normal University, China \\ (Pauljohnalegado24@yahoo.com)
}

Soe, Hnin Yu

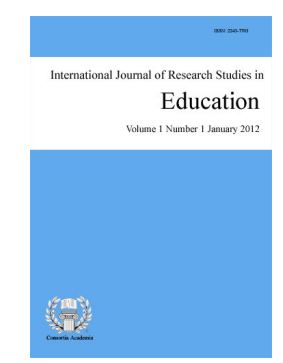

ISSN: 2243-7703 Online ISSN: 2243-7711

OPEN ACCESS

Department of Methodology, Sagaing University of Education, Myanmar

Institute of International and Comparative Education, Beijing Normal University, China (mshninyusoe@gmail.com)

\section{Abstract}

This paper is aimed at investigating the effects of mentoring on teachers' beliefs and teachers' pedagogical practices and whether the former has significant influence on the latter. To maximize the results and establish consistency, both 2013 and 2018 Teaching and Learning International Survey (TALIS) findings from lower secondary school teachers were used. Drawing from previous literature and three mentoring models, this paper offers a clear framework to better understand the elements where mentoring has impacts on and the dispositions by which mentors and mentees develop. This dyadic relationship supports the transfer of different fundamentals such as pedagogical, academic knowledge, psychosocial, attitudes and behaviors throughout the mentoring process. This perspective accentuates the significance of an ongoing relationship between mentors and mentees. Also, the statistical findings of this analysis suggest practical implications for school organizations and school leadership to design and align appropriate mentoring programs to support teachers' professional development.

Keywords: mentoring; TALIS; teachers' beliefs; teachers' pedagogical practices 


\section{A comparative analysis of the effects of mentoring among participating countries in 2013 and 2018 Teaching and Learning International Survey (TALIS)}

\section{Introduction}

A huge number of literatures elucidate that the delivery of high-quality teaching is directly interrelated to positive student learning outcomes (Henard \& Leprince-Ringuet, 2008; Henard \& Rosevear, 2012; OECD, 2009; Singh \& Sarkar, 2015). Thus, the effective conveyance of the curriculum and teaching practices are equivalently vital which puts teachers at the heart of this mission (Alegado, 2018a, 2018b; Koki, 2000; OECD, 2009; Soe, 2018). Conversely, accomplishing this undertaking whilst cultivating teacher pedagogical beliefs, attitudes and professional learning activities do not come innately to teachers pre and post their induction. Other aspects should be taken into consideration, including mentorship, and the necessity to scrutinize it more deeply is of huge importance especially if we are to consider teachers as valued assets in education. After all, high-quality teaching and performance in teaching and learning function as central ingredients for educational improvement.

In recent times, mentoring or mentorship has been attributed as a key element in the field of educational research (Alegado, 2018a; Klinge, 2015; Scandura \& Pellegrini, 2007; Soe, 2018). Mentorship can aid teachers' performance in the classroom with enormous support at any phase of a teacher's career-whether it is pre, during or post induction. Effectual mentorship programs have established significant and meaningful outcomes in teachers' induction and training of vice principals and principals alike (Ingersoll \& Strong, 2011; Zembytska, 2016; Langdon, Flint, Kromer, Ryde, \& Karl, 2011). Mentoring, moreover, is also strategic in assiduously fostering professional knowledge, attitudes and skills that the teaching force necessitates for them to teach and prepare students.

Mentoring is an umbrella word that is used to define any relationship between a more experienced professional and a less experienced professional. They are more known as mentor-mentee relationship. Bell (2000) epitomizes a mentor as an individual or professional who assists a protégé to (re)learn things that he or she might have learned less, lack of or have not learned at all. On one of the most known definitions of mentoring, Donaldson et al. (2000) described it as a dyadic, face-to-face supervision of an adult who supervises a student to support his or her overall development including theoretical knowledge, professional expertise, and skills sets. Similarly, with the teaching force in a particular school, such relationship also happens between a senior teacher and a newly-inducted teacher. This type of mentorship can differ in the way it is construed by schools whether it is informal or formally organized, the duration (long vs short term) and in some cases, how it is done, whether it is in the form of in-person mentoring or online (Alegado, 2018a; Kasprisin et al., 2003; Packard, 2003).

Progressively in recent scholarships, definitions of mentoring have become much more distinct and capacious. For example, Zachary (2002) proposes that mentoring encompasses the transfer of knowledge, allows personal development, and supports mentees with their transition. Consistent with this, Blandford (2000) defines it as an elaborate process through which not only knowledge and expertise are transferred but also some other psychological effects like more understanding and motivational skills. However, Harnish and Wild (1994) warn that mentorship should not focus on mentors alone but rather should highlight what both mentors and mentees benefit from such process because the nature of their relationship is relatively mutual.

More recently, the scholarship on mentoring in schools is centrally focused on the effects of mentoring itself to their recipients, which include theoretical, pedagogical and professional development. We made use of this fact as a starting point of this paper. This study intends to bring fresh insights through quantitative evidence using the international data from 2013 and 2018 Teaching and Learning International Survey (TALIS) results from participating countries. TALIS began in 2008 with 24 participating countries and economies, focusing on 
lower secondary education. The target samples were consisted of 200 schools per country with 20 teachers and at least one school leader/principal in each school. From its inception, TALIS has since began conducting surveys in primary and upper secondary schools. In 2013, the data we acquired from OECD on mentoring were from 32 countries (although there are 34 countries which participated), while in 2018, it increased to 47 (total participating countries is 48). The participating countries and economies are listed in Table 1. For this comparative approach, we utilized both existing data from 2013 and 2018 results in lower secondary teachers' survey. Consequently, we concentrated the analysis on two critical parts of the survey which are (1) teachers' beliefs and (2) teachers' pedagogical practices.

Teachers' belief is a colossal thought which may overlap with other psychological features like his or her knowledge, ideologies and attitudes (Pajares, 1992). Even though belief is an intertwined construct, it can simply be understood as "a game of player's choice at best" (Pajares, 1992). Borg (2003) supplemented that it is a major motivating aspect in several façades of teaching and that it can influence students' learning (Windschitl \& Sahl, 2002). Teachers' belief and teachers' pedagogical practices are highly interlaced with one another (Lopes \& Santos, 2013). Teacher's actions are substantially connected and vastly ascribed with their personal and/or professional beliefs. They can be something about their belief and attitudes towards how classroom management should be implemented or how teaching should be like, and even on how teachers should respond and approach teaching-related issues. (Evrim, Gökçe, \& Enisa, 2009; Lopes \& Santos, 2013; Shin \& Koh, 2007; Yilmaz \& Çavaş, 2008). Teachers' pedagogical practices, on the other hand, reliably impact students' learning outcomes and its significance can be argued to have been influenced by their professional and personal beliefs (Muijs \& Reynolds, 2002; Nye, Konstanopoulos, \& Hedges, 2004; Palardy \& Rumberger, 2008). Specifically, teachers' beliefs on instructional practices can be supported and enhanced by mentors during their professional training (OECD, 2009). In 2013 TALIS questionnaire, teacher belief is assessed through the following statements based on personal beliefs on teaching:

$>$ my role as a teacher is to facilitate students' own inquiry,

$>$ students learn best by finding solutions to problems on their own,

$>$ students should be allowed to think of solutions themselves, and

$>\quad$ thinking and reasoning processes are more important.

In 2018, it was slightly changed and added some beliefs on teachers themselves which included the following statements:

$>$ most teachers in this school strive to develop new ideas for teaching and learning,

$>$ most teachers in this school are open to change,

most teachers in this school search for new ways to solve problems, and

$>$ most teachers in this school provide practical support to each other for the application of new ideas.

Furthermore, teachers' pedagogical practices are simply implied as the actions done or activities undertaken by teachers into the classroom to improve students learning, classroom management and various instructional strategies (OECD, 2009). Teachers' pedagogical practice is another very broad term because its definition interweaves with other teachers' activities in the classroom. Nevertheless, it is a recognized that the classroom practices teachers utilize are imperative for efficacious student outcomes and classroom learning (Wang, Haertel, \& Walberg, 1993). Such pedagogical strategies are comprised of presentation skills, lesson organization, classroom management, informative feedback and motivational strategies which have positive influence on student achievement (Creemers \& Kyriakides, 2008; Hattie, 2009; OECD, 2009; Seidel \& Shavelson, 2007). In 2013 and 2018 TALIS questionnaire, teachers' pedagogical practices are portrayed in the following items:

get students to believe they can do well in school work,

help students value learning,

craft good questions for students,

control disruptive behavior in the classroom,

motivate students who show low interest in school work,

make my expectations about student behavior clear, 
$>$ help student think critically,

$>$ get students to follow classroom rules,

$>$ calm a student who is disruptive or noisy,

$>$ use a variety of assessment strategies,

$>$ provide an alternative explanation, for example when students are confused,

$>\quad$ vary instructional strategies in my classroom, and

$>$ support student learning through the use of digital technology (e.g. computers, tablets, smart boards etc.).

\section{Literature review}

Coaching, a synonymous form of mentoring is well documented in many professions such as in social work and teaching (McKimm, Jollie, \& Hatter, 2007). In schools, this type of continuing support from teachers' induction is becoming more prevalent as more and more organizations practice and adopt this kind of mentoring program. Arguably, entering the teaching workforce can pose many challenges to newly qualified or newly-inducted teachers. It is a delicate period that is very critical because their early experience in the profession and the kind of mentoring and support they get in the beginning can shape their perceptions, pedagogical practices and teachers' belief. It is also the time where teachers' knowledge and skills are finally applied into practice. Likewise, it is a provisional period where anxiety and stress are commonly experienced by teachers and that most of them feel the challenges caused by the strains and expectancies from the working environment. That said, this stage is where teachers need the most support and guidance for them to gain confidence and acquire the required competencies of the job. For instance, he or she can absorb the values system, norms, history and ideologies of the organization through mentorship. Having known such can prepare them and devise their expectations more suitably (Williams, 2000).

From the evolving literature on mentoring, studies have been very profound on studying mentorship as a method for professional learning (Hudson, 2013; Huling \& Resta, 2001; Nel \& Luneta, 2017). This is greatly rooted from previous findings that support the relationship between mentors and mentees. They highlighted the need for mentees to procure practices and habits of the 'community' they are about to become a part of (Merriam, 1982). Therefore, understanding these habits and core rules in the organization necessitates schools to provide support to new teachers through a type of learning called 'knowing-in-action' (Schon, 1983). It is from this perspective that mentoring in pre and post induction of teachers has been scrutinized. On the other hand, mentoring as professional development is fundamentally propositioned that most teachers learn through the process of observation then application, and feedback, rather than purely listening (Nicholls, 2012). For instance, mentoring schemes arranged by schools can induct novice teachers speedily. It also where a teacher's individual 'potential' are characterized and developed and can encourage self-development efficiently (Jones \& Jowett, 1997; Williams, 2000).

Other related literature underscored the dynamics of mentoring and studied to which qualities and aspects it has an impact on. For example, Levinson et al. (1978) stressed that mentees gain knowledge while mentors cultivate a great sense of satisfaction and confidence by mentoring the 'future' of the organization. Psychological gains such as loyalty, trust and support are also some important findings that mentors reportedly received. When a teacher is asked to 'mentor', he or she tries to show the highest level his or her performance, and therefore increases his/her visibility and self-esteem within the organization (Chao, 1997). On the other hand, mentees are more highly likely to enjoy more career advancement and salary increase (Nemanick, 2000) because mentoring impacts their performance. Generally, mentoring has positive influence on career mobility, professional growth, and career advancement. As Alegado (2018a, 2018b)) concluded, although the impacts are not precisely weighed the same on both mentees and mentors, mentorship actually benefit both parties in innumerable ways. Mentees suggestively acquire pedagogical knowledge, classroom management skills and psycho-behavioral aspects of teaching while mentors accentuated the influence of mentoring behavior on their leadership potential and the sense of satisfaction and validation, they gain from it. 


\subsection{Theoretical framework}

Previous researches showed the effects of mentoring activities on teachers' professional development (Soe, 2018). In 2002, Grossman and Rhodes found that mentoring activities can provide positive learning outcomes of students including academic achievement, self-concept and interpersonal relationship. In addition, several research findings showed that mentoring activities can provide positive outcomes for teachers. However, there is still limited research about the influence of mentoring activities on teachers' personal belief and pedagogical belief by using international data. In order to examine the effects of mentoring activities, we used three theoretical models: Zey's (1984) Mutual Benefits Model, Yob, Crawford's (2012) Mentoring Framework, and Rhodes (2002) Youth Mentoring Models as the central frameworks to explore the role of mentoring activities in teachers' belief and teachers' pedagogical practices. In TALIS, teaching practices can be seen as the activities such as learner-centered pedagogies, collaborative activities and creating positive learning environment (European Commission, 2013). Teachers' belief is described as teachers' personal beliefs and professional beliefs toward teaching profession. These were explored in 2013 and 2018 surveys consecutively.

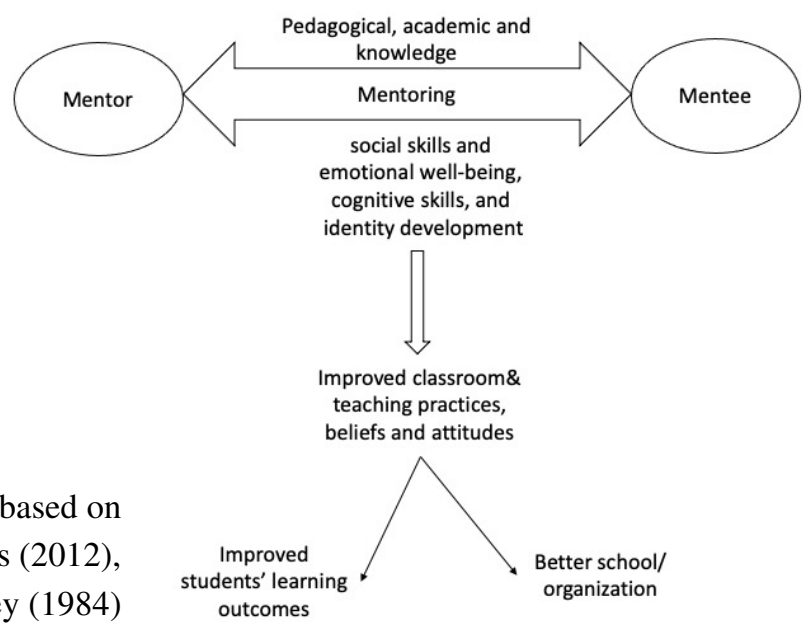

Figure 1. Mentoring framework based on Rhodes (2002), Yob \& Crawford's (2012), and Zey (1984) outcomes

Mentoring activities can be described as mentee and mentor (Ragins \& Kram, 2017). Both mentors and mentees have their distinctive roles and duties. There are many theoretical models that focused on the relationship between mentor-mentee and the mutual benefits of such relationship. Among them, Zey's (1984) Mutual Benefits Model mentioned that if the teachers participate in this relationship, they can get benefits for their professional development such as administrative, organizational and cultural characteristics. As the main role of mentor to provide this kind of information; if the mentee's performance improved, the mentor will have positive impressions about them. This dyadic relationship of mentor and mentee underlines the benefits for the school organization through providing professional learning community and collaborative teams. Therefore, this model pointed out the mutual benefits for both mentee and mentor and the school organization where they work. Mutual Benefits Model provides a basic foundation to show the importance of mentor and mentee relationship. However, this model does not suffice the necessities of this work. We need to consider how we can benefit from the mentoring relationship. Thus, we adopted another model by Yob and Crawford's (2002) Mentoring Framework. This model classifies mentoring benefits in two important areas-academic and psychosocial. The academic element denotes technical and informational functions of the mentor that support mentee development for the acquisition of knowledge, skills, and attitudes. In the academic domain, four primary qualities were predictable: (1) competence, (2) availability, (3) induction, and (4) challenge. On the other hand, psychosocial domain embodies "the qualities and skills in building and sustaining interpersonal relationships, and the values, attitudes, and affects involved in mentoring” (p. 41). In this aspect, three qualities have emerged which includes (1) the faculty member's personal qualities, (2) communication, and (3) emotional support.

This was further explained by the model used by Rhodes' (2002) which suggested that mentoring activities 
Alegado, P. J. E., \& Soe, H. Y.

can influence professional development in three ways: (1) by improving social skills and emotional well-being; (2) by developing cognitive skills through dialogue and listening; (3) identity development. The purpose of Rhodes' model is to conclude that the mentoring relationship can enhance the individual development through strong, interpersonal connection built upon mutuality and trust. Rhodes (2005) mentioned that mentoring relationship can improve the social and emotional well-being by providing opportunities for fun and relief from daily stresses and correcting emotional experiences and assisting emotional regulation. Mentoring relationship may influence the cognitive development by introducing new opportunities for learning, and aid in different challenges and academic issues. Furthermore, mentoring activities may contribute to develop positive identity development by relating individuals' conception of both their current and their future identities (Rhodes et al., 2006). Therefore, mentoring activities and relationship can provide positive individual improvement.

Likewise, Kram (1983) theorized mentoring to have influence on both career development and psychosocial aspects. She differentiates these two functions as:

"career functions those aspects of the relationship that primarily enhance career advancement," such as sponsorship, exposure-and-visibility, coaching, protection, and challenging assignments. Whereas, psychosocial functions are those aspects of the relationship that primarily enhance the sense of competence, clarity of identity, and effectiveness in the managerial role, such as role modeling, acceptance-and-confirmation, counseling, and friendship (p. 614).

As previously mentioned, this model explains the positive impact of mentoring activities on teachers' professional and personal development. Although this model is not perfect to show the significance of mentoring, it can provide the basic connection and foundations to the importance of mentoring on teachers' pedagogical practices and teacher's beliefs.

\section{Methodology}

\subsection{Research questions and hypothesis}

$>\quad$ RQ1 - Is there significant difference in teachers' personal beliefs in terms of mentoring activities (mentee and mentor) in both TALIS 2013 and 2018 international data?

$>\quad \mathbf{H 1}$ - There is significant difference in teachers' personal beliefs in terms of mentoring activities (mentee and mentor) in both TALIS 2013 and 2018 international data.

$\diamond \quad$ H1(a) - There is significant difference in teachers' beliefs between mentee and non-mentee in both TALIS 2013 and 2018 international data.

$\diamond \quad$ H1(b) - There is significant difference in teachers' beliefs between mentor and non-mentor in both TALIS 2013 and 2018 international data.

RQ2 - Is there significant difference in teachers' pedagogical practices in terms of mentoring activities (mentee and mentor) in both TALIS 2013 and 2018 international data?

$>\quad \mathbf{H} \mathbf{2}$ - There is significant difference in teachers' pedagogical practices in terms of mentoring activities (mentee and mentor) in both TALIS 2013 and 2018 international data.

$\diamond \quad$ H2(a) - There is significant difference in teachers' pedagogical practices between mentee and non-mentee in both TALIS 2013 and 2018 international data.

$\diamond \quad \mathbf{H 2}(\mathbf{b})$ - There is significant difference in teachers' pedagogical practices between mentor and non-mentor in both TALIS 2013 and 2018 international data.

50 Consortia Academia Publishing (A partner of Network of Professional Researchers and Educators) 
$>\quad$ RQ3 - Is there significant influence of teachers' beliefs on teachers' pedagogical practices in both TALIS 2013 and 2018 international data?

> $\mathbf{H 3}$ - There is significant influence of teachers' personal beliefs on teachers' pedagogical practices in both 2013 and 2018 TALIS international data

\subsection{Sample}

In this paper, the secondary data sets (BTGINTT2) and (BTGINTT3) were used. "B": lower secondary education (ISCED level 2); "T": teacher-level data file. "G" is used for general questionnaire data. "IN": International and "T2" is used for the second round of TALIS conducted in 2013 and "T3" is used for the third round of TALIS conducted in 2018.

\subsection{Source of data}

For the purpose of this paper, secondary data was used from 2013 and 2018 TALIS international data. In this questionnaire, the portion of teaching general especially in teachers' beliefs and teachers' pedagogical practices was used and the role of mentoring activities in teachers' belief and teachers' pedagogical practices was studied. The items that indicate mentoring activities were arranged with "yes" or "no" answer through the following statements:

$>$ I currently have an assigned mentor to support me.

$>$ I am currently assigned mentor for one or more teacher.

The items that pertained to teachers' belief and teachers' pedagogical practices were used and were introduced at the beginning of this paper. For teachers' belief and teachers' pedagogical practices, the items are arranged with Likert scale, and for mentoring activities, the items are arranged with "yes" and "no". For the mentoring activities, the item numbers, (TT2G20A and TT2G20B in 2013 data, TT3G21A and TT3G21B in 2018 data) were used. For the teachers' pedagogical beliefs, TT3G32A to TT3G32D and for the teaching practices and behaviors in the classroom, TT3G34A to TT3G34M were used.

\subsection{Method of analysis}

Secondary data was analyzed by using Statistical Package for Social Science (SPSS) version (20). Descriptive statistics and inferential statistics were used to analyze the data. The number of participants in the 2013 international data and 2018 international data are shown in Table (1) and (2).

Table 1

Number of participants in the BTGINTT2 (TALIA, 2013)

\begin{tabular}{|c|c|c|c|c|c|c|c|}
\hline Country & Male & Female & Total & Country & Male & Female & Total \\
\hline Australia & 847 & 1212 & 2059 & Mexico & 1489 & 1647 & 3136 \\
\hline Brazil & 4626 & 9665 & 14291 & Netherland & 883 & 1029 & 1912 \\
\hline Bulgaria & 541 & 2431 & 2975 & Norway & 1132 & 1849 & 2981 \\
\hline Chile & 635 & 1041 & 1676 & Poland & 971 & 2887 & 3858 \\
\hline Croatia & 953 & 2722 & 3675 & Portugal & 953 & 2675 & 3628 \\
\hline Czech Republic & 813 & 2406 & 3219 & Romania & 944 & 2342 & 3286 \\
\hline Denmark & 670 & 979 & 1649 & Serbia & 1320 & 2537 & 3857 \\
\hline Estonia & 526 & 2601 & 3129 & Singapore & 1070 & 2039 & 3109 \\
\hline Finland & 778 & 1961 & 2739 & Slovak Republic & 667 & 2862 & 3493 \\
\hline France & 1040 & 1962 & 3002 & Spain & 1365 & 1974 & 3339 \\
\hline Israel & 841 & 2562 & 3403 & Sweden & 1124 & 2195 & 3319 \\
\hline Italy & 740 & 2597 & 3337 & Abu Dhabi (UAE) & 969 & 1464 & 2433 \\
\hline Japan & 2102 & 1382 & 3484 & Alberta & 705 & 1068 & 1773 \\
\hline Korea & 896 & 2037 & 2933 & England & 918 & 1578 & 2496 \\
\hline Latvia & 253 & 1873 & 2126 & Flanders & 1044 & 2085 & 3129 \\
\hline \multirow[t]{2}{*}{ Malaysia } & 869 & 2115 & 2984 & United States & 656 & 1269 & 1925 \\
\hline & & & & Total & 33345 & 71010 & 104355 \\
\hline
\end{tabular}

Source. Teaching and Learning International Survey (2013). 
Alegado, P. J. E., \& Soe, H. Y.

Table 2

Number of participants in the BTGINTT3 (TALIS, 2018)

\begin{tabular}{|c|c|c|c|c|c|c|c|}
\hline Country & Male & Female & Total & Country & Male & Female & Total \\
\hline Australia & 2246 & 1327 & 3573 & Malta & 1140 & 516 & 1656 \\
\hline Austria & 2955 & 1300 & 4255 & Mexico & 1625 & 1301 & 2926 \\
\hline Belgium & 3639 & 1617 & 5256 & Netherlands & 1012 & 872 & 1884 \\
\hline Brazil & 1621 & 826 & 2447 & New Zealand & 1483 & 773 & 2256 \\
\hline Bulgaria & 2289 & 573 & 2862 & Norway & 2675 & 1479 & 4154 \\
\hline Chile & 1276 & 687 & 1963 & Portugal & 2681 & 995 & 3675 \\
\hline Chinese(Taipei) & 2606 & 1229 & 3835 & Russian Federation & 3422 & 589 & 4011 \\
\hline Colombia & 1298 & 1100 & 2398 & Saudi Arabia & 1544 & 1200 & 2744 \\
\hline Croatia & 2605 & 753 & 3358 & Singapore & 2102 & 1178 & 3280 \\
\hline Cyprus & 1181 & 430 & 1611 & Slovak Republic & 2451 & 564 & 3015 \\
\hline Czech Republic & 2607 & 840 & 3447 & Vietnam & 2517 & 1308 & 3825 \\
\hline Denmark & 1203 & 798 & 2001 & Slovenia & 1650 & 444 & 2094 \\
\hline Estonia & 2479 & 525 & 3004 & South African & 1226 & 820 & 2046 \\
\hline Finland & 1985 & 866 & 2851 & Spain & 4625 & 2782 & 7407 \\
\hline France & 1951 & 1055 & 3006 & Sweden & 1827 & 955 & 2782 \\
\hline Georgia & 2625 & 476 & 3101 & UAE & 5244 & 3404 & 8648 \\
\hline Hungary & 2550 & 695 & 3245 & Turkey & 2286 & 1666 & 3952 \\
\hline Israel & 1955 & 672 & 2627 & United State & 1717 & 837 & 2554 \\
\hline Italy & 2809 & 803 & 3612 & England & 1537 & 839 & 2376 \\
\hline Japan & 1510 & 2045 & 3555 & Canada & 680 & 397 & 1077 \\
\hline Kazakhstan & 5023 & 1543 & 6566 & Romania & 2650 & 1008 & 3658 \\
\hline Korea & 2025 & 906 & 2931 & Argentina & 1442 & 657 & 2099 \\
\hline Latvia & 2038 & 277 & 2315 & China (Shanghai) & 2941 & 1035 & 3976 \\
\hline Lithuania & 3170 & 589 & 3759 & Total & 106123 & 47551 & 153674 \\
\hline
\end{tabular}

\section{Results and findings}

The first part of the findings is the descriptive results which showed the mean values of teachers' personal belief and teachers' pedagogical practices. The second part of the findings is the inferential result which showed the significant difference in teachers' beliefs and pedagogical practices in terms of mentoring activities by using $t$ test and the influence of teachers' belief on teachers' pedagogical practices by using regression analysis.

Table 3

Mean score for teachers' belief and teachers' pedagogical practices (TALIS, 2013)

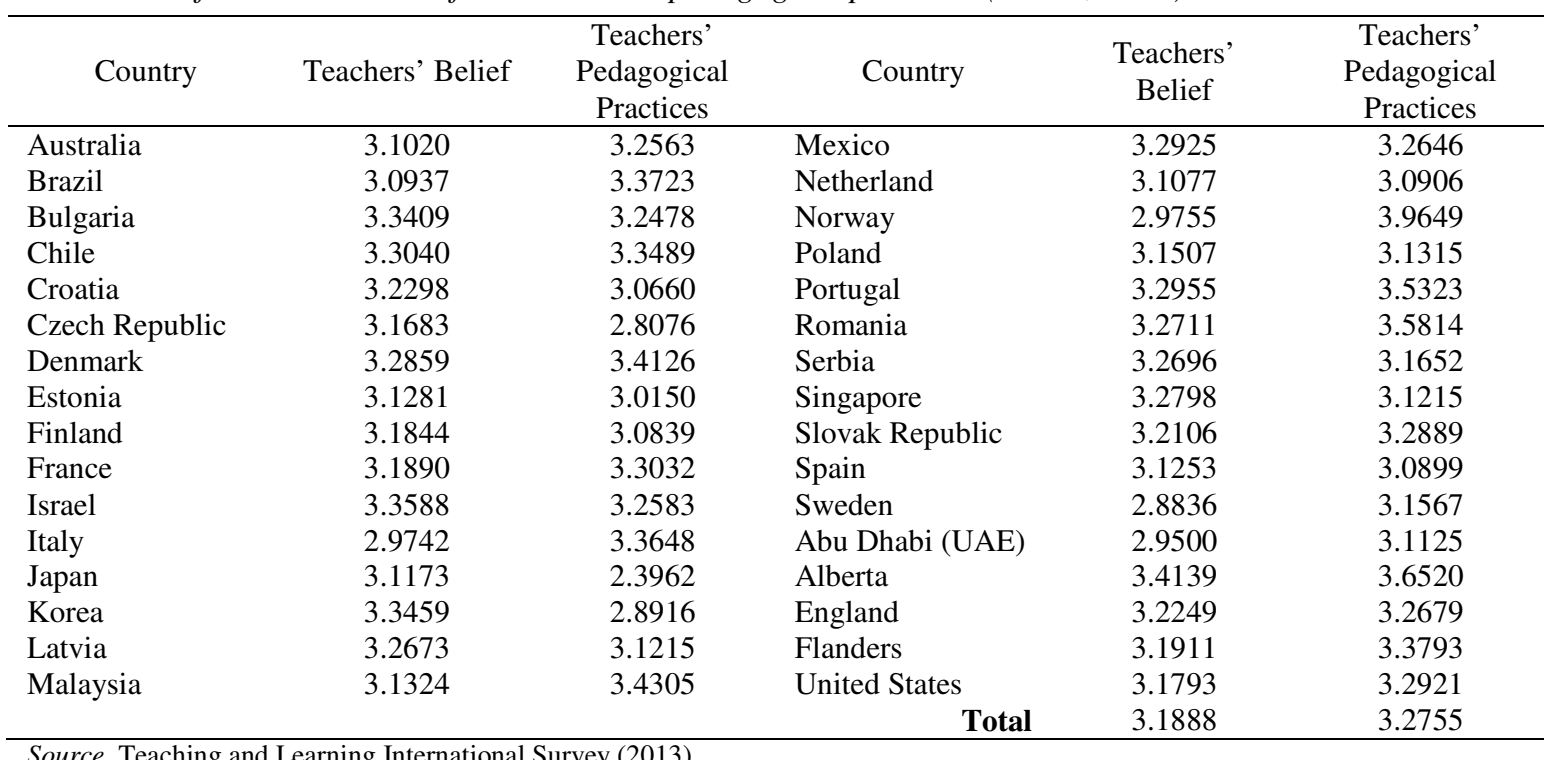

52 Consortia Academia Publishing (A partner of Network of Professional Researchers and Educators) 
A comparative analysis of the effects of mentoring among participating countries in 2013 and 2018 TALIS

Table 4

Mean score for teachers' belief and teachers' pedagogical practices (TALIS, 2018)

\begin{tabular}{|c|c|c|c|c|c|}
\hline Country & Teachers' Belief & $\begin{array}{c}\text { Teachers' } \\
\text { Pedagogical } \\
\text { Practices } \\
\end{array}$ & Country & $\begin{array}{c}\text { Teachers' } \\
\text { Belief }\end{array}$ & $\begin{array}{c}\text { Teachers' } \\
\text { Pedagogical } \\
\text { Practices } \\
\end{array}$ \\
\hline Australia & 2.8933 & 3.2385 & Malta & 2.8862 & 3.2771 \\
\hline Austria & 2.9619 & 3.1151 & Mexico & 3.0009 & 3.2181 \\
\hline Belgium & 2.6988 & 3.1478 & Netherlands & 2.6931 & 3.2838 \\
\hline Brazil & 3.0309 & 3.3430 & New Zealand & 2.9005 & 3.2360 \\
\hline Bulgaria & 3.1127 & 3.3100 & Norway & 2.9776 & 2.8700 \\
\hline Chile & 2.9712 & 3.2956 & Portugal & 2.6672 & 3.5597 \\
\hline Chinese(Taipei) & 2.8410 & 3.0394 & Russian Federation & 3.0009 & \\
\hline Colombia & 3.0511 & 3.6631 & Saudi Arabia & 3.1428 & 3.4488 \\
\hline Croatia & 2.8063 & 2.9898 & Singapore & 2.8447 & 3.1496 \\
\hline Cyprus & 2.7377 & 3.3963 & Slovak Republic & 2.9500 & 3.1125 \\
\hline Czech Republic & 2.7687 & 2.9497 & Vietnam & 3.2752 & 3.4012 \\
\hline Denmark & 2.9662 & 3.4032 & Slovenia & 2.9990 & 3.1061 \\
\hline Estonia & 2.9076 & 3.0493 & South African & 2.8917 & 3.4469 \\
\hline Finland & 2.8467 & 3.1029 & Spain & 2.8777 & 3.0914 \\
\hline France & 2.8339 & 2.9535 & Sweden & 2.9141 & 3.1213 \\
\hline Georgia & 3.2124 & 3.3000 & UAE & 3.2549 & 3.5725 \\
\hline Hungary & 3.0404 & 3.3937 & Turkey & 3.0131 & 3.2774 \\
\hline Israel & 2.8880 & 3.2351 & United State & 2.9212 & 3.2300 \\
\hline Italy & 2.8294 & 3.3127 & England & 2.9055 & 3.3050 \\
\hline Japan & 2.8435 & 2.4774 & Canada & 3.0081 & 3.2936 \\
\hline Kazakhstan & 3.1324 & 3.1407 & Romania & 3.1761 & 3.2976 \\
\hline Korea & 2.9287 & 3.0858 & Argentina & 3.0028 & 3.3125 \\
\hline Latvia & 3.1183 & 3.1674 & China (Shanghai) & 3.1737 & 3.2884 \\
\hline Lithuania & 3.0834 & 3.1199 & & & \\
\hline
\end{tabular}

Source. Teaching and Learning International Survey (2018).

\section{Hypothesis (1)}

There is significant difference in teachers' personal beliefs in terms of mentoring activities (mentee and mentor) in both 2013 and 2018 TALIS international data.

$H 1(a)$ - There is significant difference in teachers' beliefs between mentee and non-mentee in both 2013 and 2018 TALIS international data.

Figure 2. The Comparison of Mean Scores for the Teachers' Beliefs in term of Mentee and Non-mentee



An independent-samples t-test was conducted to compare teachers' belief in mentee and non-mentee. In TALIS, 2013 data, there was a significant difference in the scores for mentee $(\mathrm{M}=3.2224, \mathrm{SD}=0.50558)$ and non-mentee $(\mathrm{M}=3.1865, \mathrm{SD}=0.48053)$ conditions; $\mathrm{t}(110793)=8.772, p=.000$. In TALIS, 2018 data, there was a significant difference in the scores for mentee $(\mathrm{M}=3.1192, \mathrm{SD}=0.61908)$ and non-mentee $(\mathrm{M}=2.9479$, $\mathrm{SD}=0.62224)$ conditions; $\mathrm{t}(147001)=35.493, p=.000$. Based on both data (TALIS 2013 and 2018), both these results suggest that training of mentee activity really does have an effect on teachers' belief. Specifically, our results suggest that when teachers are assigned as mentees, their teachers' beliefs will be significantly higher. 
Alegado, P. J. E., \& Soe, H. Y.

$H 1(b)$ - There is significant difference in teachers' beliefs between mentor and non-mentor in both 2013 and 2018 TALIS international data.

Figure 3. The Comparison of Mean Scores for the Teachers Beliefs in term of

Mentor and Non-mentor



An independent-samples $t$-test was conducted to compare teachers' belief in mentor and non-mentor. In TALIS, 2013 data, there was a significant difference in the scores for mentor $(M=3.2578, S D=0.49193)$ and non-mentor $(\mathrm{M}=3.1818, \mathrm{SD}=0.48192)$ conditions; $\mathrm{t}(109784)=18.262, p=.000$. In TALIS, 2018 data, there was a significant difference in the scores for mentor $(M=3.0572, S D=0.62031)$ and non-mentor $(M=2.9555$, $\mathrm{SD}=0.62360$ ) conditions; $\mathrm{t}(146747)=21.842, p=.000$. Based on both data (TALIS 2013 and 2018), these results suggest that training of mentor activity really does have an effect on teachers' belief. Specifically, our results suggest that when the teachers are assigned as mentors, their teachers' belief will be higher.

\section{Hypothesis (2)}

There is significant difference in teachers' pedagogical practices in terms of mentoring activities (mentee and mentor) in both 2013 and 2018 TALIS international data.

$H 2(a)$ - There is significant difference in teachers' pedagogical practices between mentee and non-mentee in both 2013 and 2018 TALIS international data.

Figure 4. The Comparison of Mean Scores for the Teachers' Pedagogical

Practices in term of Mentee and

Non-mentee



An independent-samples $t$-test was conducted to compare teachers' pedagogical practices in mentee and non-mentee. In TALIS, 2013 data, there was a significant difference in the scores for mentee $(\mathrm{M}=3.2422$, $\mathrm{SD}=0.53577)$ and non-mentee $(\mathrm{M}=3.2192, \mathrm{SD}=0.47918)$ conditions; $\mathrm{t}(108928)=5.515, p=.000$. In TALIS, 2018 data, there was a significant difference in the scores for mentee $(\mathrm{M}=3.2784, \mathrm{SD}=0.54192)$ and non-mentee $(\mathrm{M}=3.2001, \mathrm{SD}=0.48113)$ conditions; $\mathrm{t}(140737)=20.169, p=.000$. Based on both data (TALIS 2013 and 2018), these results suggest that training of mentee activity really does have an effect on teachers' pedagogical practices. Specifically, our results suggest that when the teachers are assigned as mentees, their pedagogical practices will be better. 
$H 2(b)$ - There is significant difference in the teachers' pedagogical practices between mentor and non-mentor in both 2013 and 2018 TALIS international data.

Figure 5. The Comparison of Mean Scores for the Teachers' Pedagogical Practices in term of Mentor and Non-mentor

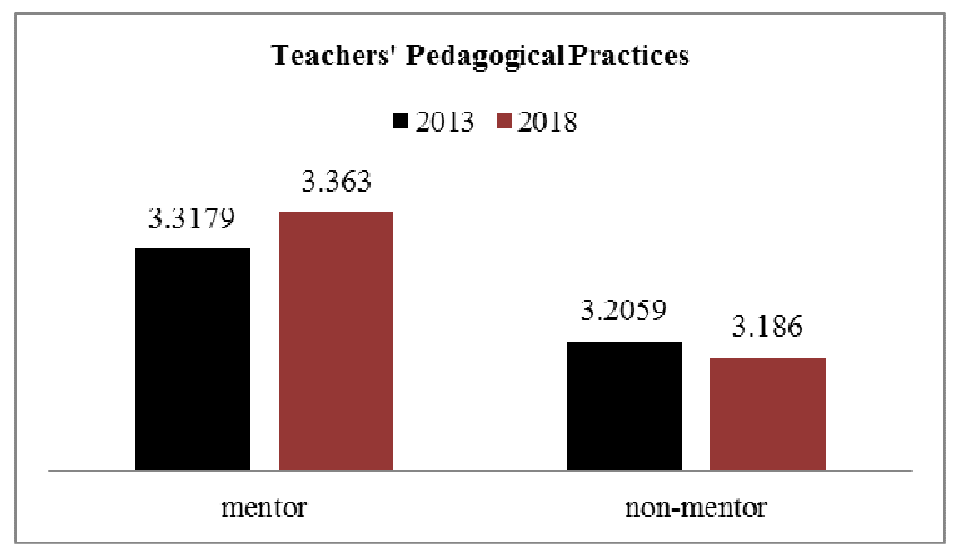

An independent-samples t-test was conducted to compare teachers' pedagogical practices in mentor and non-mentor. In TALIS, 2013 data, there was a significant difference in the scores for mentor $(\mathrm{M}=3.3179$, $\mathrm{SD}=0.48700)$ and non-mentor $(\mathrm{M}=3.2059, \mathrm{SD}=0.48631)$ conditions; $\mathrm{t}(107994)=26.554, p=.000$. In TALIS, 2018 data, there was a significant difference in the scores for mentor $(\mathrm{M}=3.3630, \mathrm{SD}=0.48465)$ and non-mentor $(\mathrm{M}=3.1860, \mathrm{SD}=0.48601)$ conditions; $\mathrm{t}(140576)=47.559, p=.000$. Based on both data (TALIS 2013 and 2018), these results suggest that training of mentor activity really does have an effect on teachers' pedagogical practices. Specifically, our results suggest that when the teachers are assigned as mentor, their pedagogical practices will be better.

\section{Hypothesis (3)}

There is significant influence of teachers' personal belief on teachers' pedagogical practices in both 2013 and 2018 TALIS international data. In hypothesis 3, teachers' personal belief is the independent variable and the teachers' pedagogical practices are the dependent variable. To test the hypothesis, regression analysis was used and the results for both TALIS (2013) and TALIS (2018) are as follows.

In 2013 data, the overall regression model is significant $(\mathrm{F}(1)=3375.600, p<.001$, teachers' belief is a variable which could be used to predict teachers' pedagogical practices $(\mathrm{t}=58.100, p<.001)$. The correlation between the true $\mathrm{Y}$ and the predict $\mathrm{Y}$ is .173 , the coefficient of the determinant .030 , which indicated that the regression model could explain $3.0 \%$ of the total variance among the teachers' pedagogical practices.

$$
\text { Teacher pedagogical practices }=2.639+.172 * \text { Teachers' belief }
$$

In 2018 data, the overall regression model is significant $(F(1)=5725.992, p<.001$, teachers' belief is a variable which could be used to predict teachers' pedagogical practices $(\mathrm{t}=75.670, p<.001)$. The correlation between the true $\mathrm{Y}$ and the predict $\mathrm{Y}$ is .197 , the coefficient of the determinant .039 , which indicated that the regression model could explain $3.9 \%$ of the total variance among the teachers' pedagogical practices.

$$
\text { Teacher pedagogical practices }=2.754+.154 * \text { Teachers' belief }
$$

\subsection{Summary of the findings}

A. There is significant difference in teachers' personal beliefs in terms of mentoring activities (mentee and mentor) in both 2013 and 2018 TALIS international data.

B. There is significant difference in teachers' pedagogical practices in terms of mentoring activities (mentee and mentor) in both 2013 and 2018 TALIS international data. 
C. There is significant influence of teachers' personal beliefs on teachers' pedagogical practices in both 2103 and 2018 TALIS international data.

The purpose of this study is to compare the effects of mentoring by using TALIS (2013) second round data and TALIS (2018) third round data. There were three research questions posed by this paper. Based on the results, mentoring activities have influence on teachers' beliefs and teachers' pedagogical practices and they are consistent in both samples. In addition, results showed that teachers' pedagogical belief is a predictor for teachers' pedagogical practices. Overall, the research findings supported the effects of mentoring on teacher's professional development in both TALIS (2013) and (2108) data.

\section{Conclusion and practical implications}

Competent and effective teaching requires all teachers to employ a broad spectrum of skills, have innovative access to rich teaching repertoires and have a closer look at his/her own teaching. These capabilities do not come naturally to teachers and therefore must be developed through other means like mentoring. Mentoring activities and approaches can be beneficial for both mentees and mentors as proven by this quantitative analysis of TALIS 2013 and TALIS 2018 with respect to (1) teachers' beliefs and (2) teachers' pedagogical practices.

For many years, known literatures on teaching and mentoring have developed frameworks of classroom management and models of students' behaviors which cautiously integrate teachers' beliefs, teachers' values, and teachers' principles (Livingston, McClain, \& Despain, 1995; Lopes \& Santos, 2013; Sato \& Kleinsasser, 2004). These researches elucidate teachers' actions are deeply rooted from teachers' beliefs about learning and educational goals, beliefs about what is deemed 'good' or 'bad' teaching, and their individual theories about their roles as teachers to their students. Congruently, teachers' beliefs and theories about teaching are understood to intercede teachers' actions and behaviors in class, and when viewed from a bigger picture can in turn model students' behavior and academic performance (Elias \& Mace, 2005; Lopes \& Santos, 2013).

The results of the statistical analysis indicate that there is a significant difference in teachers' beliefs between mentee and non-mentee and between mentor and non-mentor. There is also a significant difference in the pedagogical practices between mentee and non-mentee and between mentor and non-mentor. And finally, teachers' belief has significant influence on teachers' pedagogical practices. Thus, the result indicates that mentoring is highly relevant for teachers in schools in light of the statistical nature of this analysis. We reviewed the significance of mentoring in two aspects: (1) teachers' beliefs and (2) teachers' pedagogical practices and therefore found that they both have positive relationship. We expect that the findings on this paper will motivate institutions to design and align new mentoring programs, framed in the context of teachers' beliefs and teachers' pedagogical practices.

The results of this paper have further implications mainly in organizations like schools. For instance, formal mentoring programs develop future mentors and an organizational mentoring culture (Ragins \& Scandura, 1999). Organizations that enthusiastically cultivate novice teachers are also developing future mentors. For schools that have not taken on promoting this kind of mentoring relationships as part of their organizational culture, this paper recommends taking an affirmative role to tap potential mentors who have not been in a mentoring role. These schools should also endorse the development of mentoring by incorporating them in career development programs and performance appraisals. School leaders and administrators need to realize that creating an environment that allows experienced teachers to mentor novice or less experienced teachers will for sure profit the students and the overall organization will improve as a result of the increased capacity of teachers serving as mentors and mentees. The theoretical framework we presented supports mentoring as a professional development and should come as a precedence for education sectors and leaders. Capitalizing on teachers' professional development can build system capacity through mutually beneficial exchange, transfer and/or acquisition of pedagogical practices and positive beliefs. 
Data availability statement: Supplementary data for the current study is available at http://www.oecd.org/education/talis/talis-2013-data.htm

http://www.oecd.org/education/talis/talis-2018-data.htm

\section{References}

Alegado, P. J. E. (2018a). A qualitative investigation of the effects of mentoring: Teachers' narrative from Tianjin, China. Journal of Teaching and Training, 5(2), 112-126. https://doi.org/10.5296/jet.v5i2.13285

Alegado, P. J. E. (2018b). The challenges of teacher leadership in the Philippines as experienced and perceived by teachers. International Journal of Education and Research, 6(6), 291-302

Bell, C. R. (2000). The mentor as partner. Training and Development, 54(2), 52-61.

Borg, S. (2003). Teacher cognition in language teaching: A review of research on what language teachers think, know, believe, and do. Language Teaching, 36(2), 81-109. https://doi.org/10.1017/S0261444803001903

Blandford, S. (2000). Managing professional development in schools. Routledge.

Chao, G. T. (1997). Mentoring phases and outcomes. Journal of Vocational Behavior, 51, 15- 28. https://doi.org/10.1006/jvbe.1997.1591

Clement, M., \& Vandenberghe, R. (2000). Teachers' professional development: A solitary or collegial (ad)venture? Teaching and Teacher Education, 16, 81-101. https://doi.org/10.1016/S0742-051X(99)00051-7

Creemers, B. P., \& Kyriakides, L. (2006). Critical analysis of the current approaches to modelling educational effectiveness: The importance of establishing a dynamic model. School Effectiveness and School Improvement, 17(3), 347-366. https://doi.org/10.1080/09243450600697242

Donaldson, S. I., Ensher, E. A., \& Grant-Vallone, E. J. (2000). Longitudinal examination of mentoring relationships on organizational commitment and citizenship behavior. Journal of Career Development, 26, 233-249. https://doi.org/10.1177/089484530002600401

European Commission. (2003). The teaching and learning international survey (TALIS) 2013: Main findings from the survey and implication for education and training policies in Europe. Education and Training. http://ec.europa.eu/dgs/education_culture/repository/education/library/reports/2014/talis_en.pdf

Evrim, E. A., Gökçe, K., \& Enisa, M. (2009). Exploring the relationship between teacher beliefs and styles on classroom management in relation to actual teaching practices: a case study. Procedia: Social and Behavioral Sciences, 1(1), 612-617. https://doi.org/10.1016/j.sbspro.2009.01.109

Freeman, C., O'Malley, K., \& Eveleigh, F. (2014). Australian teachers and the learning environment: An analysis of teacher response to TALIS 2013: Final report. ACER.

Grossman, J., \& Rhodes, J. (2002). The test of time: Predictors and effects of duration in youth mentoring relationships. American Journal of Community Psychology, 30(2), 199.

Harnish, D., \& Wild, J. A. (1994). Mentoring strategies for faculty development. Studies in Higher Education, 19(2), 19(2), 191-201. https://doi.org/10.1080/03075079412331382037

Hénard, F., \& Roseveare, D. (2012). Fostering quality teaching in higher education: Policies and practices. OECD.

Henard, F., \& Leprince-Ringuet, S. (2008). The path to quality teaching in Higher Education. Programme Institutional Management for Higher Education, 1-50. http://www.oecd.org/dataoecd/10/60/41692318.pdf

Hudson, P. (2013). Mentoring as professional development: 'Growth for both' mentor and mentee. Professional Development in Education, 39(5), 771-783. https://doi.org/10.1080/19415257.2012.749415

Huling, L., \& Resta, V. (2001). Teacher mentoring as professional development. ERIC Clearinghouse on Teaching and Teacher Education, Washington DC.

Ingersoll, R., \& Strong, M. (2011). The impact of induction and mentoring programs for beginning teachers: A critical review of the research. Review of Education Research, 81(2), 201-233. https://doi.org/10.3102/0034654311403323 
Alegado, P. J. E., \& Soe, H. Y.

Isac, M. M., da Costa, P. D., Araújo, L., Calvo, E. S., \& Albergaria-Almeida, P. (2015). Teaching practices in primary and secondary schools in Europe: Insights from large-scale assessments in education. Joint Research Centre, European Commission.

Jones, C., \& Jowett, V. (1997). Managing facilities. Butterworth Heinemann.

Kasprisin, C. A., Single, P. B., Single, R. M., \& Muller, C. B. (2003). Building a better bridge: Testing e-training to improve e-mentoring programs for diversity in higher education. Mentoring \& Tutoring, 11(1), 67-78. https://doi.org/10.1080/1361126032000054817

Klinge, C. (2015). A conceptual framework for mentoring in a learning organization. Adult Learning, 26(4), 160-166. https://doi.org/10.1177/1045159515594154

Koki, S. (2000). The role of teacher mentoring in educational reform. Pacific Resources for Education and Learning, 808, 1-6.

Kyriakides, L., Campbell, R. J., \& Gagatsis, A. (2000). The significance of the classroom effect in primary schools: An application of Creemers' comprehensive model of educational effectiveness. School Effectiveness and School Improvement, 11(4), 501-529. https://doi.org/10.1076/sesi.11.4.501.3560

Langdon, F., Flint, A., Kromer, G., Ryde, A., \& Karl, D. (2011). Induction and mentoring pilot programme: Primary leading learning in induction and mentoring. New Zealand Teachers Council.

Levinson, D. J., Darrow, C. N., Klein, E. B., Levinson, M. A., \& McKee, B. (1978). Season's of a man's life. Knopf.

Livingston, M. J., McClain, B. R., Despain, B. C., (1995). Assessing the consistency between teachers' philosophies and educational goals. Education, 116(1), 124-129.

McKimm J., Jollie, C., \& Hatter, M., (2007). Mentoring: Theory and practice. Preparedness to practice. Imperial College School of Medicine.

Merriam, S. (1983). Mentors and protégés: A critical review of the literature. Adult Education Quarterly, 33, 161-173.

Muijs, D., \& Reynolds, D. (2002). Teachers' beliefs and behaviors: What really matters? Journal of Classroom Interaction, 38(1), a343. https://doi.org/10.4102/pythagoras.v38i1.343

Nel, B., \& Luneta, K. (2017). Mentoring as professional development intervention for mathematics teachers: A South African perspective. Pythagoras, 38(1), a343. https://doi.org/10.4102/pythagoras.v38i1.343

Nicholls, G. (2012). Mentoring: The art of teaching and learning. Kogan Page Limited.

Nye, B., Konstantopoulos, S., \& Hedges, L. V. (2004). How large are teacher effects? Educational Evaluation and Policy Analysis, 26(3), 237-257. https://doi.org/10.3102/01623737026003237

OECD. (2019). Creating effective teaching and learning environments: First results from TALIS. Berlin, Germany.

Packard, B. W. (2003). Web-based mentoring: Challenging traditional models to increase women's access. Mentoring \& Tutoring, 11(1), 53-65. https://doi.org/10.1080/1361126032000054808

Pajares, F. (1992). Teachers' beliefs and educational research: Cleaning up the messy construct. Review of Educational Research, 62(3), 307-332. https://doi.org/10.3102/00346543062003307

Palardy, G. J., \& Rumberger, R. W. (2008). Teacher effectiveness in first grade: The importance of background qualifications, attitudes, and instructional practices for student learning. Educational Evaluation and Policy Analysis, 30(2), 111-140. https://doi.org/10.3102/0162373708317680

Ragins, B. R., \& Scandura, T. A. (1999). Burden or blessing: Expected costs and benefits of being a mentor. Journal of Organizational Behavior, 20, 493-509. https://doi.org/10.1002/(SICI)1099-1379(199907)20:4<493::AID-JOB894>3.0.CO;2-T

Rhodes, J. E. (2002). Stand by me: The risks and rewards of mentoring today's youth. Harvard University Press.

Rhodes, J. E. (2005). A model of youth mentoring. In D. L. DuBois \& M. J. Karcher (Eds.), Handbook of youth mentoring (pp. 30-43). Sage.

Rhodes, J., Spencer, R., Keller, T., Liang, B., \& Noam, G. (2006). A model for the influence of mentoring relationships on youth development. Journal of Community Psychology, 34(6), 691-707. https://doi.org/10.1002/jcop.20124

Rosenholtz, S. J. (1989) Teachers' workplace: The social organization of schools. Longman.

58 Consortia Academia Publishing (A partner of Network of Professional Researchers and Educators) 
A comparative analysis of the effects of mentoring among participating countries in 2013 and 2018 TALIS

Sato, K., \& Kleinsasser, R. C. (2004). Beliefs, practices, and interactions of teachers in a Japanese high school English department. Teaching and Teacher Education, 20(8), 797-816. https://doi.org/10.1016/j.tate.2004.09.004

Scandura, T. A., \& Pellegrini, E. K. (2007). Workplace mentoring: Theoretical approaches and methodological issues. In T. D. Allen \& L. T. Eby (Eds.), Handbook of mentoring: A multiple perspective approach (pp. 71-91). Blackwell.

Schon, D. (1983). The reflective practice. Basic Books.

Seidel, T., \& Shavelson, R. J. (2007). Teaching effectiveness research in the past decade: The role of theory and research design in disentangling meta-analysis results. Review of Educational Research, 77(4), 454-499. https://doi.org/10.3102/0034654307310317

Singh, R., \& Sarkar, S. (2015). Does teaching quality matter? Student learning outcome related to teaching quality in public and private primary schools in India. International Journal of Educational Development, 41, 153-163. https://doi.org/10.1016/j.ijedudev.2015.02.009

Shin, S., \& Koh, M. S. (2007). A crosscultural study of teachers' beliefs and strategies on classroom behavior management in Urban American and Korean school systems. Education and Urban Society, 39(2), 286-309. https://doi.org/10.1177/0013124506295280

Soe, H. Y. (2018). The impact of teachers' professional development on the teachers' instructional practices: An analysis of TALIS 2013 teacher questionnaire, Finland. World Voices Nexus, 2(3), 7.

Windschitl, M., \& Sahl, K. (2002). Tracing teachers' use of technology in a laptop computer school: The interplay of teacher beliefs, social dynamics, and institutional culture. American Educational Research Journal, 39(1), 165-205. https://doi.org/10.3102/00028312039001165

Yilmaz, H., \& Çavaş, P. H. (2008). The effect of the teaching practice on pre-service elementary teachers' science teaching efficacy and classroom management beliefs. Eurasia Journal of Mathematics, Science and Technology Education, 4(1), 45-54. https://doi.org/10.12973/ejmste/75305

Zachary, L. J. (2002). The role of teacher as mentor. New Directions for Adult and Continuing Education, 93, 27-38. https://doi.org/10.1002/ace.47

Zembytska, M. (2016). Mentoring as the core element of new teacher induction in the USA: Policies and practices. Comparative Professional Pedagogy, 6(2), 67-73. https://doi.org/10.1515/rpp-2016-0021

Zey, M. G. (1984). The mentor connection. Dow-Jones-Irwin. 
Alegado, P. J. E., \& Soe, H. Y.

60 Consortia Academia Publishing (A partner of Network of Professional Researchers and Educators) 